\title{
O nieistnieniu i normatywności wartości
}

\author{
Andrzej Niemczuk \\ (D) https://orcid.org/0000-0002-8886-4254
}

\begin{abstract}
Celem artykułu jest uzasadnienie dwóch twierdzeń: 1) że wartości nie należą do zakresu pojęcia bytu; 2) iż są dla podmiotu obowiązujące, pomimo że nie mają obiektywnego istnienia. Pierwszy fragment artykułu zawiera krytykę ontologii wartości. We fragmentach następnych autor przedstawia argumentację za następującymi tezami pozytywnymi: 1) obiekty wartościowe to obiekty uczuć słusznych; 2) kryterium słuszności uczuć jest, stwierdzana przez samowiedzę i rozum, niesprzeczność ich treści ze szczęściem podmiotu; 3) treść szczęścia, afirmowana przez wolną decyzję (pradecyzję), jest treścią pierwszej aksjologicznej przesłanki w rozumowaniach praktycznych; 4) źródłem normatywności wartości jest ludzkie pragnienie bycia podmiotem, które obejmuje afirmację własnej wolności i racjonalności. Proponowane w artykule stanowisko aksjologiczne sytuuje się pomiędzy dwiema krytykowanymi skrajnościami: pomiędzy obiektywistyczną ontologią wartości i subiektywistycznym emotywizmem.
\end{abstract}

Słowa kluczowe: wartości, normatywność, szczęście

Mimo że filozofia wartości, czy też aksjologia ogólna, przez około 100 lat przeżywała niezwykle bujny rozkwit (od końca wieku XIX do lat 80. wieku XX), to jednak podstawowe jej pytanie nie doczekało się zadowalającej odpowiedzi.

ANDRZEJ NIEMCZUK, doktor habilitowany, prof. UR, Instytut Filozofii, Wydział Socjologiczno-Historyczny (Kolegium Humanistyczne), Uniwersytet Rzeszowski; adres do korespondencji: al. T. Rejtana 16 C, 35-959 Rzeszów; e-mail: aniemczuk@ur.edu.pl 
Idzie mi o pytanie: „czy i jak wartości istnieją?” Można nawet stwierdzić, że zaproponowane odpowiedzi na to pytanie ciągle pozostają najbardziej kontrowersyjne spośród różnorakich poglądów wysuniętych w dziedzinie aksjologii.

Teoretyczna sytuacja samego tego pytania jest zresztą nader osobliwa. Utworzenie i rozwój filozoficznej teorii wartości były oparte na argumencie, wedle którego ta nowa dziedzina filozofii konieczna jest dlatego, że wartości i cała sfera normatywności pozostają poza kompetencjami filozofii bytu (ontologii). Argument ten był z kolei ufundowany na rozpoznaniu I. Kanta, wykazującym, iż z wiedzy o tym, co jest (o faktach), nie wynika żadna imperatywna wiedza o wartościach (o dobru $)^{2}$. Akceptacja tego Kantowskiego rozpoznania nie tylko nie pozwalała na obejmowanie zakresem ontologii problemów dotyczących wartości, ale wręcz zastosowanie ontologii do aksjologii wykluczała. Stara metafizyka mówiąca o doskonałości i dobru metafizycznym (obecna jeszcze w systemie Hegla) musiała zatem zostać oczyszczona $\mathrm{z}$ owych nieuzasadnionych wtrętów aksjologicznych i - jako ograniczona wyłącznie do teorii bytu - wymagała uzupełnienia przez autonomiczną wobec niej filozofię wartości. Taką argumentację na rzecz potrzeby filozofii wartości spotykamy najpierw u R. H. Lotzego, a następnie w filozofii neokantystów badeńskich - szczególnie w zorientowanej systemowo myśli H. Rickerta $^{3}$. Jeśli więc aksjologia powstała jako reakcja na rozpoznaną bezradność logiczną ontologii wobec problemu wartości, to trzeba zauważyć, że sensu stricto ontologiczne pytanie o sposób istnienia wartości jest - jak się zdaje - z góry skazane na porażkę. Ignoruje ono bowiem rozpoznanie, które zrodziło odrębność aksjologii od ontologii.

${ }^{2}$ Celowo wymieniam tu Kanta, a nie Hume’a, ponieważ: (a) tłumaczę merytoryczne powody powstania aksjologii, a ona w XIX w. powstała w filozofii niemieckiej (R. H. Lotze, noekantyści), gdzie znajomość i oddziaływanie filozofii Kanta były powszechne; (b) „gilotyna Hume’a” zaczęła być powszechnie znana dopiero w wieku XX, po odkryciu błędu naturalistycznego przez G. E. Moore’a - nie miała więc wpływu na powstanie aksjologii; (c) sam Hume nie przestrzegał swojej „gilotyny”, podczas gdy Kant konsekwentnie respektował swoją zasadę niewywodzenia sądów etycznych z sądów aposteriorycznych (empirycznych).

${ }^{3}$ Por. Herbert Schnädelbach, Filozofia w Niemczech 1831-1933, tłum. Krystyna Krzemieniowa (Warszawa: PWN, 1992), 271-275; Heinrich Rickert, „Tezy do systemu filozofii”, tłum. Beata BorowiczSierocka, w: Neokantyzm, red. Beata Borowicz-Sierocka, Czesław Karkowski (Wrocław: Wydawnictwo Uniwersytetu Wrocławskiego, 1984), 45-54. 
Sedno przedstawionego, „niemieckiego” argumentu powołującego do istnienia aksjologię - jako dziedzinę autonomiczną wobec ontologii - zostaje historycznie powtórzone na początku XX wieku w kręgu świeżo powstałej i rozwijającej się filozofii analitycznej (brytyjsko-austriackiej). Mam oczywiście na myśli linię myślenia o wartościach przebiegającą od G. E. Moore’a, poprzez wczesnego L. Wittgensteina, a kontynuowaną przez Koło Wiedeńskie oraz metaetyczny emotywizm (Ch. Stevenson, A. J. Ayer). Odkryty przez tego pierwszego tzw. błąd naturalistyczny w etyce nie pozwalał stosować deskryptywnej wiedzy o tym, co istnieje, do wyjaśniania wartości. Niecałe 20 lat później Wittgenstein twierdzi, że wartości nie mogą być elementami świata (przedmiotu ontologii), zaś neopozytywiści i emotywiści - na tej samej podstawie - głoszą, iż wartości nie ma w świecie faktów (i dlatego nie są przedmiotem intersubiektywnej wiedzy opisowej), lecz stanowią jedynie wytwory indywidualnych uczuć ${ }^{4}$.

Różnica w tych dwóch wymienionych sposobach myślenia, które stanowiły podwaliny dla powstającej aksjologii ogólnej, polegała jedynie na tym - z najbardziej ogólnego punktu widzenia - że proponowano inne rozwiązania alternatywne wobec zgodnie ustalonej, kłopotliwej diagnozy o niemożliwości zastosowania wiedzy o świecie (ontologicznej i naukowej) do formułowania i uzasadniania filozofii wartości. Podczas gdy linia filozofii analitycznej - można rzec: pośpiesznie i beztrosko - poszła w kierunku skrajnej subiektywizacji wartości i w gruncie rzeczy wykluczenia ich z zakresu racjonalnej argumentacji (poza G. E. Moore'em), to wspomniana linia niemiecka szukała sposobu na uratowanie intersubiektywnego ich obowiązywania i zachowania ich w obrębie racjonalnego dyskursu, pomimo utraty ich fundamentu ontologicznego. To właśnie w kontekście owego niemieckiego, w pewnym sensie desperackiego, ratowania „obiektywnej ważności” wartości H. Rickert sformułował paradoksalne twierdzenie, głoszące, że „wartości nie istnieją, ale obowiązują"5. Otóż moją intencją w niniejszy artykule jest obrona pewnej wersji tego twierdzenia.

\footnotetext{
${ }^{4}$ Koncepcje wartości autorów wymienionych w powyższym akapicie analizowałem merytorycznie w: Andrzej Niemczuk, Stosunek wartości do bytu. Dociekania metafizyczne (Lublin: Wydawnictwo UMCS, 2005), rozdz. 3 - Rozwój aksjologii; por. też Jacek Hołówka, Relatywizm etyczny (Warszawa: PWN, 1981).

${ }^{5}$ Por. Heinrich Rickert, „Sens i wartość”, w: Neokantyzm, wstęp i wybór tekstów Beata Trochimska-Kubacka, tłum. Beata Trochimska-Kubacka, Janina Gajda-Krynicka (Wrocław: Wydawnictwo Uniwersytetu Wrocławskiego, 1997), 111-120.
} 
W świetle przytoczonego argumentu, fundującego powstanie aksjologii, pytanie ,jak istnieją wartości?” wydaje się popadać w błąd kategorialny - w swoim mijaniu się z naturą przedmiotu, którego dotyczy, jest podobne na przykład do pytania „ile ważą liczby?” Twór teoretyczny zwany „ontologią wartości” musi się natomiast jawić jako egzemplifikacja błędu contradicto in adjecto. Jeśli wartości są czymś innym niż byty - a założenie takie jest ratio essendi aksjologii nie będącej regionem ontologii - to ontologiczne pytania dotyczące wartości są oparte na błędnych założeniach. Na pytanie zaś o błędnym założeniu dopóty nie można odpowiedzieć trafnie, dopóki nie zmieni się jego założenia. Warto zaznaczyć, że przedstawiona tu argumentacja jest oparta nie tylko na odwołaniu się do historycznych nurtów, które wyłoniły aksjologię, ale także (a nawet przede wszystkim) na ściśle merytorycznej koncepcji błędu naturalistycznego. Można zatem tę kwestię zrekapitulować tak oto: jeśli respektujemy teorię błędu naturalistycznego, to wartości nie mogą być bytami, czyli nie mogą wchodzić w zakres kategorii istnienia. Niemniej jednak, nadal pytaniem otwartym pozostaje problem ich obowiązywania i jego uzasadnienia.

Jeśli natomiast idzie o kwestię ontologii wartości, to jej źródłem było - jak się zdaje - skrzyżowanie ze sobą dwóch nowych, wysuniętych pod koniec wieku XIX, koncepcji filozoficznych. Jedna stanowiła reinterpretację pojęcia ontologii, druga zaś - reinterpretację teorii uczuć. Filozofem, który obie te reinterpretacje połączył w jedną teorię wartości, był A. Meinong. Ontologia, wedle jego projektu, przestała być tradycyjną teorią bytu (tego, co istnieje), lecz stała się teorią wszelkich przedmiotów, czyli korelatów aktów umysłowych - bez względu na to, czy owe korelaty istnieją, czy nie (daseinsfrei). W teorii uczuć zaś Meinong przejął od swojego nauczyciela F. Brentana tezę, wedle której uczucia są aktami poznawczymi (mają charakter intencjonalny) ${ }^{6}$. Właśnie skrzyżowanie tych dwóch twierdzeń doprowadziło do powstania ontologii wartości: ponieważ uczucia mają swoje własne przedmioty poznania, którymi są wartości, a ontologia jest teorią przedmiotów, toteż, oprócz ontologii innych przedmiotów, możliwa i potrzebna jest także ontologia takich przedmiotów, jak wartości. Wartości włączono więc w zakres ontologii (wbrew przytoczonej wcześniej argumentacji zarówno niemieckiej, jak i analitycznej) za cenę - można rzec - wyrzucenia z tego zakresu

${ }^{6} \mathrm{O}$ aksjologii A. Meinonga por. John Niemeyer Findlay, Meinong's Theory of Objects and Values (Oxford: Clarendon Press, 1963); por. też Hanna Buczyńska-Garewicz, Uczucia i rozum w świecie wartości (Wrocław: Wydawnictwo PAN, 1975), 115-158. 
samego bytu (tego, co istnieje) oraz przyznania uczuciom charakteru poznawczego. Podobny schemat ontologii wartości utwierdził się następnie w całej aksjologii fenomenologicznej - począwszy już od samego E. Husserla, aż po R. Ingardena i jego mniej lub bardziej wiernych następców. W całym tym nurcie funkcjonuje zasada następująca: jeśli wartości są przedmiotami poznania uczuciowego, a ontologia stanowi teorię tego, co jawi się świadomości poznającej, to sensowna i prawomocna, oprócz innych ontologii regionalnych, jest także ontologia wartości.

Idea stosowalności ontologii do wyjaśniania wartości uzyskała również dodatkowe i silne wsparcie ze strony ontologii krytycznej N. Hartmanna. Pomimo że systematycznie i szczegółowo rozwinięta ontologia Hartmanna przekracza znacznie fragmentaryczne koncepcje ontologiczne Meinonga, to jednak, jeśli idzie o samą ideę aplikacji ontologii do ujęcia wartości, Meinongowskie warunki tej aplikacji zostają u Hartmanna w zasadzie powtórzone. Z jednej strony bowiem Hartmann utrzymuje, że ontologia tkwi u podstaw każdej dziedziny filozoficznej (ponieważ wszystko, co poznajemy, musi jakoś istnieć) ${ }^{7}$, z drugiej zaś - podtrzymuje on pewną wersję tezy o poznawaniu wartości przez uczucia. W efekcie tego uprawiana przez niego aksjologia zostaje zredukowana do ontologii wartości, której podstawowe twierdzenie głosi, iż wartości są bytami idealnymi ${ }^{8}$.

$\mathrm{Na}$ podstawie powyższych uwag można stwierdzić, że pytanie o istnienie wartości jest zazwyczaj rozstrzygane na dwa przeciwstawne sposoby. Albo się twierdzi, że są one bytami, aczkolwiek innymi niż byty realne (czyli bytami idealnymi lub intencjonalnymi), albo przeciwnie - sądzi się, że nie należą one do bytu i nie są przedmiotem wiedzy, lecz stanowią wytwory subiektywnych postaw uczuciowych. Warto zauważyć, że gdy na pytanie „czy wartości istnieją?” odpowiada się „tak” lub „nie”, to zakłada się, że pytanie to leży w zakresie kompetencji ontologii. Warto także zwrócić uwagę na kwestię ważniejszą, a mianowicie na to, i̇̇ oba te typy odpowiedzi ze wszech miar nie są zadowalające jako stanowiska na

${ }^{7}$ Por. Nicolai Hartmann, „Systematyczna autoprezentacja”, w: Nicolai Hartmann, Myśl filozoficzna i jej historia. Systematyczna autoprezentacja, tłum. Jan Garewicz (Toruń: Wydawnictwo Comer, 1994).

${ }^{8}$ Por. Nicolai Hartmann, „O idealnej samoistności wartości”, w: $Z$ fenomenologii wartości, tłum. i red. Włodzimierz Galewicz (Kraków: PAT, 1988), 85-101. 
temat natury wartości - ontologia nie dysponuje zaś możliwością innej odpowiedzi na to pytanie niż tylko te dwie. Jakkolwiek by niuansować sposoby i formy istnienia, ostatecznie i tak musi się okazać, że wartości albo istnieją, albo nie.

Jeśli wartości istnieją (czyli są bytami), to wykazanie ich obowiązywalności musi napotkać „rafę” tzw. błędu naturalistycznego. A ponadto, w konceptualizacji działania praktycznego owe aksjologiczne byty - po ich rozpoznaniu przez podmiot - muszą się okazać ontycznymi determinantami czynu, co z kolei wtrąca taką konceptualizację w determinizm aksjologiczny. Jeżeli zaś wartości są jedynie wytworami subiektywnych uczuć (czyli, precyzyjniej mówiąc, nieistniejącymi przedmiotami złudzeń uczuciowych), to niepojęte musi pozostać to, jakie racje stoją za intersubiektywnym domaganiem się respektowania owych uczuciowych złudzeń. Innymi słowy, ten nihilistyczny subiektywizm w pojmowaniu wartości jest o wiele bardziej bezradny w wytłumaczeniu normatywności oraz w objaśnieniu racjonalności działania niż wspomniany wcześniej zontologizowany obiektywizm.

Przedstawione tutaj wstępne uwagi o problemie istnienia wartości pokazują, że poprawną filozofią wartości byłaby tylko taka, która potrafiłaby pogodzić ze sobą dwie podstawowe tezy: (a) że wartości nie należą do zakresu pojęcia istnienia (nie są bytami) oraz (b) że jednak obowiązują i podlegają racjonalnej argumentacji. Próbę pogodzenia tych dwóch tez przedstawia dalszy mój wywód.

\section{Wartości w perspektywie ontologicznej}

Gdy na przełomie XIX i XX wieku aksjologia pojawiła się na mapie dyscyplin filozoficznych, to nie wyrosła z filozofii praktycznej (ani Arystotelesowskiej, ani Kantowskiej), lecz ukonstytuowała się jako nowa część filozofii teoretycznej skupiona badawczo na równie świeżo skonstruowanym pojęciu wartości. Z jednej strony, była ona filozoficzną reakcją na poheglowski upadek metafizyki (a szczególnie - na destrukcję tradycyjnej koncepcji dobra metafizycznego) oraz na uświadamianą stopniowo konsekwencję tego upadku w postaci narastającego nihilizmu. Z drugiej strony, intencją powstającej aksjologii ogólnej było dostarczenie - właśnie przy braku metafizyki - nowego filozoficznego ugruntowania dla wszystkich nauk traktujących o celowych aktywnościach człowieka (wszak aktywności celowe muszą zakładać jakieś wartości). Filozofię praktyczną, przeważnie zredukowaną do etyki, powstająca filozofia wartości traktowała właśnie jako jedną 
ze swoich subdyscyplin - jako praktyczną konkretyzację ogólnej teorii wartości". Ów teoretyczny punkt widzenia, jaki rozwijająca się aksjologia niemal powszechnie przyjmowała (może poza neokantystami), niejako automatycznie wtrącał ją w ontologiczną perspektywę problematyzowania i wyjaśniania kwestii wartości - jest to tym bardziej zrozumiałe, im bardziej pojmowanie ontologii oddala ją od bytu, a przybliża do „teorii przedmiotu”. Można w przybliżeniu powiedzieć, że jeśli tylko jakiś aksjolog nie poprzestawał na samej jedynie epistemologii wartości, to jego teoria wkraczała na teren twierdzeń ontologicznych. Co więcej, koncepcje utrzymywane $\mathrm{w}$ granicach epistemologii wartości także implikowały wyraźne, choć rzadko jawnie eksplikowane, konkluzje ontologiczne (np. nonkognitywizm emotywistów i neopozytywistów, z którego jednoznacznie wynikało, że wartości nie istnieją, lub intuicjonizm, czy to G. E. Moore’a, czy E. Husserla, który implikuje jakieś obiektywne istnienie wartości).

Gdy w perspektywie teoretyczno-ontologicznej problematyzuje się pytanie o wartości, to narzucającą się ich konceptualizacją jest następujący sposób myślenia o nich. Przedmiot wartościowy to taki, który ma cechę (jakiejś) wartości, tak jak przedmiot barwny ma cechę (jakiejś) barwy. Wydaje się więc, że wartości są jakimiś cechami lub własnościami przedmiotów. Gdy następnie chce się sprecyzować charakter tych własności, to możliwe są oczywiście dwa kierunki ich interpretacji - albo obiektywistyczny, albo subiektywistyczny. Jeśli ktoś chce zmierzać w kierunku obiektywistycznym, to musi przyjąć jakiś rodzaj intuicjonizmu (np. tezę o intencjonalności uczuć), bo poza odwołaniem się do intuicji nie da się wskazać żadnego sposobu poznania takich cech, jak wartości. Obiektywiści dochodzą więc do wniosku, że przedmioty i zdarzenia posiadają dwa rodzaje własności: jedne poznawane „normalnie” (przez doświadczenie zmysłowe i/lub rozum), a drugie poznawane intuicyjnie (i one są właśnie wartościami). Pomijając wszystkie czysto epistemologiczne trudności, jakie wytwarza tak pojęty intuicjonizm (przede wszystkim problemy z intersubiektywnością), warto na początek zauważyć, że wynikające stąd pojmowanie wartości jako ontycznych cech przedmiotów musi prowadzić do ontologicznego regresu w nieskończoność. Jeśli bowiem każdy byt posiada jakąś wartość (własność wartości), to taki byt, jak własność wartości, musi również mieć jeszcze dodatkową wartość, a ona następną. Subiektywi-

${ }^{9}$ O teoretycznym charakterze powstającej w XIX w. aksjologii oraz o marginalizacji przez nią filozofii praktycznej pisałem szerzej w: Stosunek wartości do bytu, 63-73. 
styczna natomiast interpretacja cechy wartości polega w istocie na tym, że nie akceptuje intuicjonizmu aksjologicznego (np. tezy o intencjonalności uczuć). W wyniku niezgody na poznanie intuicyjne typowa argumentacja subiektywistów jest następująca: skoro dostępnymi środkami poznawczymi nie poznajemy w przedmiotach cech wartości (opinie o nich nie są intersubiektywne), to cechy te nie są cechami przedmiotów, lecz są na przedmioty rzutowane przez przygodne (niepoznawcze) uczucia. Ontologiczna konkluzja subiektywistów orzeka więc, że wartości są subiektywne, a to znaczy, że cechy wartości nie istnieją. Konkluzja taka zaś musi pociągać za sobą jeszcze jeden wniosek, którego jednak większość subiektywistów zazwyczaj nie wypowiada, a mianowicie, że wszystkie sądy wartościujące są błędne. Warto też dodać, że ten ontologiczny nihilizm głoszony w subiektywistycznej interpretacji wartości idzie w parze z wykluczeniem sfery aksjologicznonormatywnej z zakresu racjonalnej argumentacji - dzieje się to zaś za sprawą związania wartościowań z irracjonalnymi uczuciami.

Ontologiczne traktowanie wartości jako własności obiektów ma swój odpowiednik w językowej strukturze sądów wartościujących. Schemat takich sądów jest następujący: sąd typu „obiekt $X$ (fakt lub byt) jest wartościowy” pojmuje się jako równoważny z sądem „obiekt $X$ posiada wartość $w^{\prime}$. Kto zaufa takiemu automatyzmowi języka, ten potraktuje pojęcia wartościujące jako predykaty, a w konsekwencji - desygnaty tych pojęć uzna za własności obiektów (i tym samym wartości zontologizuje). Z kolei subiektywistyczna interpretacja sądów wartościujących, z racji braku intersubiektywnej wiedzy o ich przedmiocie, odmawia im bądź sensowności (Wittgenstein i neopozytywiści), bądź znaczenia (emotywiści), przypisując im rozmaite funkcje pozapoznawcze i - w efekcie - pozaracjonalne (wyrażanie uczuć lub perswazja).

Chociaż nie jest w istocie ważne, czy przytaczane tu argumenty mają charakter językowo-logiczny, czy stricte ontologiczny (w końcu wszak wychodzi na to samo, gdyż jedne od drugich nie są niezależne), to jednak przy tym pierwszym sposobie argumentacji łatwiej można dostrzec arbitralność i braki obecne w ontologizowania wartości. Uwaga skupiona na sądach łatwiej bowiem przesuwa się na pytanie o ich uzasadnienie. Jak natomiast można uzasadnić sąd typu „obiekt $X$ posiada wartość $w^{\prime \prime}$ ? Jeśli w uzasadnieniu wymieni się ontyczne własności obiektu, nawet wszystkie, to niestety, nie będzie to uzasadnienie sądu o jego war- 
tości. Z żadnego sądu orzekającego, że obiekt ma jakąś własność bytową (nieaksjologiczną) nie wynika, iż z tego powodu posiada on także jakąś wartość. O braku tego wynikania wiadomo od dawna na podstawie teorii błędu naturalistycznego.

Żeby z sądów o cechach ontycznych przedmiotu mogły wynikać sądy o jego cechach aksjologicznych (o jego wartościach), do przesłanek wnioskowania musi być dołączona odpowiednia przesłanka wartościująca. Na przykład, jeśli chcemy uzasadnić sąd, iż nóż jest wtedy wartościowy, gdy jest ostry, to uzasadnienie to musimy oprzeć na przesłance aksjologicznej, orzekającej że „w odniesieniu do noży ostrość jest wartościowa". Wprowadzenie owej przesłanki aksjologicznej także jednak wymaga, rzecz jasna, uzasadnienia. Poszukiwanie dla niej uzasadnienia odsyła natomiast z konieczności do podmiotu wnioskującego - do jego najrozmaitszych inklinacji: chęci, zamiarów, dążeń, pragnień, uczuć etc. Cecha ostrości uzasadnia wartość noża dlatego, że podmiot potrzebuje narzędzia do krojenia. Właśnie z tego powodu, że sądów wartościujących nie można uzasadnić w obrębie samych sądów przedmiotowych, czyli za pomocą empirycznych i ontologicznych sądów o przedmiocie wartościowym, subiektywistyczna interpretacja odmawia wartościom istnienia, przenosząc je w sferę podmiotowej arbitralności. $Z$ tą negatywną tezą subiektywistów, wedle której wartości nie są żadnymi bytami, należy się, moim zdaniem, zgodzić. Nie można i nie należy się natomiast zgadzać z pozytywnymi uzupełnieniami, jakie dodają oni - jako wyjaśnienie alternatywne - do owej prawdziwej tezy negatywnej. Wysuwane przez nich wyjaśnienia pozytywne opierają się na takiej oto regule: „ponieważ wartości pochodzą od uczuć podmiotu, to - podobnie jak kaprysy - nie podlegają uzasadnieniu i racjonalności, a w konsekwencji, nie przysługuje im intersubiektywna powinność (charakter normatywny)". Otóż właśnie wyrażony w tej regule subiektywistyczny irracjonalizm aksjologiczny jest $\mathrm{z}$ wielu powodów nieakceptowalny - przede wszystkim ze względu na jego ewidentnie nihilistyczne konsekwencje.

Przed analizą wspomnianych, koniecznych przy wyjaśnianiu wartości, odniesień do podmiotu, warto podsumować powyższe uwagi krytyczne na temat ontologii wartości.

1. Jeśli istnienie nie jest wartościowością (a nie wiadomo, dlaczego miałoby być), czyli jeśli pojęcie wartości jest różne od pojęcia istnienia, to w zakres pojęcia istnienia nie mogą wchodzić wartości. Zaliczanie ich do tego zakresu (twierdzenie, że one istnieją), jest operacją ściśle podobną pod względem logicznym np. do umieszczania barwy w zakresie pojęcia „długość”. Wprawdzie jeden i ten sam byt 
może być zarazem istniejący i wartościowy („posiadać” zarazem istnienie i wartość), ale nie może - bez dodatkowych przesłanek - ani być wartościowy dlatego, $\dot{z}$ ejest istniejący, ani być istniejący dlatego, że jest wartościowy. Jakiś $\mathrm{X}$ jest bytem dlatego, $\dot{z} e$ „posiada” istnienie, ale nie dlatego jest wartościowy - posiadana przez niego wartość ani nie czyni go bytem, ani sama nie jest żadnym bytem. Gdyby była bytem, nie byłaby wartością - mogłaby jedynie jakąś wartość „posiadać”. Inaczej mówiąc, jeśli wartości są istniejącymi cechami bytów (jeśli są bytami), to numerycznie jeden byt, gdy posiada jedną wartość, to musi posiadać numerycznie nieskończenie wiele wartości (ontologiczne regressus ad infinitum).

2. Jeśli wartości są bytami, to odnoszący się do nich język jest deskryptywny. Z sądów wyrażonych w takim języku nie ma zaś logicznego przejścia do sądów normatywnych. Wartości bez normatywności przestają natomiast być wartościami (błąd naturalistyczny).

3. Jeśli wartości są bytami, to ich poznanie determinuje czyny. Wtedy byt poznanej wartości heteronomicznie wyznacza kierunek działania, wykluczając autonomię podmiotu (determinizm aksjologiczny).

4. Jeśli wartości obiektu są bytami innymi niż jego cechy ontyczne (które stanowią jego określoność bytową), to muszą być poznawane w sposób tajemniczy, czyli intuicyjny. Skoro zaś intuicja jest poznaniem bezpośrednim, to musi być nieomylna. Jeżeli dwa akty intuicyjne zwrócone na ten sam obiekt różnią się co do rozpoznanej jego wartości (a różnice w ocenach tego samego obiektu są niezaprzeczalnym faktem), to jedynym możliwym wytłumaczeniem tej niezgodności jest twierdzenie mówiące, że część ludzi posiada intuicje niesprawne. Niestety, ponieważ nie istnieje sposób ustalenia, której części ludzi ów defekt dotyczy (jedni ludzi przeciwko drugim mogą bowiem w tej sytuacji używać jedynie argumentów ad personam), toteż nigdy nie będziemy znać prawdziwej wartości obiektów, a wszystkie „spory o wartości” z zasady będą musiały pozostać nierozstrzygnięte (intuicjonistyczna nierozstrzygalność).

Respektując powyższe argumenty, trzeba odrzucić twierdzenie o istnieniu wartości. Nie mogą one być kolejnymi cechami „przyklejonymi” do niezależnych od świadomości bytów. Jeśli są w jakimś sensie obiektywne (w jakimś sensie niearbitralne), to obiektywność ta musi oznaczać coś innego niż niezależny od podmiotu byt wartości. 


\section{Problem podmiotowych podstaw wartości}

Skoro wyjaśnienie wartości w pozapodmiotowym języku ontologii nie wytrzymuje krytyki, to - jak wspomniałem - w poszukiwaniu zadowalającego ich ujęcia trzeba się odwołać do ich związku z podmiotem. Konieczność uwzględnienia podmiotowych źródeł wartości nasuwa jednak podstawowe pytanie: do czego mianowicie, wyjaśniając je, należy w podmiocie się odwołać?

Subiektywistyczny sposób tłumaczenia wartości, który właśnie w podmiocie szuka ich podstaw, odwołuje się zazwyczaj do jakichś, występujących w podmiocie, biologicznych lub psychologicznych faktów. W ramach takiej strategii wyjaśniania powstaje typowy pogląd subiektywistyczny, którego ogólna formuła brzmi następująco: wartościowe są te obiekty, które podmiot wyróżnia swoimi pragnieniami, zainteresowaniami, upodobaniami, potrzebami etc. Nie jest $\mathrm{w}$ istocie ważne, jaką podmiotową inklinację się tu wymieni i jakiego pojęcia się użyje - mimo że subiektywiści często żarliwie i drobiazgowo dyskutowali kwestię, jaki rodzaj psychicznej aprobaty jest źródłem wartości. Nie jest to ważne dlatego, że przedmiotami wszystkich tego typu stwierdzeń pozostają - takie lub inne, ale w końcu zawsze - jedynie psychobiologiczne fakty. Ważne jest natomiast to, że z twierdzeń o faktach w żaden sposób nie wynikają twierdzenia o wartościach, w związku z czym wywodzone w ten sposób wnioski o wartościach pozostają bezzasadne. Zakres tego krytycznego spostrzeżenia należy zresztą rozszerzyć i, oprócz faktów, objąć nim również byty. Znaczy to, że jeśli ktoś próbuje uzasadnić twierdzenia o wartościach opierając je logicznie na ontologicznych twierdzeniach o podmiocie, to jego rozumowanie również jest bezzasadne - jak już bowiem wspomniałem, za pomocą twierdzeń ontologicznych (o bytach) nie można uzasadnić twierdzeń aksjologicznych (o wartościach). Warto zauważyć, że konsekwencja tego rozszerzonego spostrzeżenia sięga nader daleko. Wynika z niego bowiem, że jeśli jakaś teoria wartości wyjaśnia je wprawdzie podmiotowo (fundując je jakoś na istnieniu podmiotu), ale sam podmiot pojmuje jako jedynie rodzaj bytu, to podlega takiej samej krytyce, jak powyższa - wtedy bowiem ontyczne cechy podmiotu są bezzasadnie traktowane jako prawomocna podstawa wartości. Biorąc bowiem rzecz czysto logicznie, $\mathrm{z}$ ontologicznych twierdzeń o podmiocie nie wynika, że to, co wspomaga lub umożliwia jego istnienie, jest wartościowe. Owszem, takie wynikanie by zachodziło, ale tylko wtedy, gdyby włączyć weń pierwszą przesłankę aksjologiczną o treści: istnienie podmiotu jest wartościowe. 
Pozostaje jednak problem, jak tę pierwszą przesłankę uprawomocnić - wszak z sądu, że podmiot istnieje (że jest bytem), nie wynika, że jest wartościowy. Zarysowany tu dowód niemożliwości wywnioskowania aksjologii z ontologii dotyczy więc nie tylko ontologii świata, ale $\mathrm{w}$ równym stopniu także ontologii podmiotu (o ile to rozróżnienie w ogóle jest potrzebne).

Pomimo że wartości nie ma $\mathrm{w}$ dziedzinie bytu, to jednak występują one w sferze stosunków między podmiotem a rzeczywistością. Ich występowanie polega na tym, że - jako treści ocen - określają one i kierunkują upodobania (uczucia pozytywne) i praktyczne działania podmiotu. Dlatego też można powiedzieć, że wartości nie ma w świecie tylko wtedy, gdy patrzy się na niego teoretycznie, kiedy zaś pozostaje się do niego w stosunku praktycznym - co zachodzi właściwie ciągle, poza rzadkimi „wzlotami” teoretyzowania - czyli wtedy, gdy się w rzeczywistości praktycznie żyje i się ją odczuwa, każdy jej element jawi się jako wręcz „oblepiony” wartościami (zwykle bowiem jeden obiekt ma więcej niż jedną wartość). Można w związku z tym zauważyć, że o ile sama istniejąca rzeczywistość, jak również jej teoria w postaci ontologii, wcale nie nasuwają pytania o wartości, o tyle ludzka praktyka nie może się bez niego obejść - zarówno próby jej zrozumienia, jak i, tym bardziej, jej czynne dokonywanie. W odniesieniu do wartości ma więc zastosowanie zasada następująca: „dowodem” ich występowania, który wymusza zadanie ich wyjaśnienia, jest ludzka praktyka - pod jednym wszakże warunkiem, a mianowicie, pod warunkiem, że założymy wolność człowieka. Jeśli tego założenia nie przyjmiemy, to sposób wyjaśniania praktyki nie tylko nie będzie potrzebował wartości, ale nawet je wykluczy - wtedy bowiem całość praktyki, łącznie z przekonaniami wartościującymi, będziemy musieli tłumaczyć wyłącznie przyczynowo. Pomijając jednak ten skrajny determinizm (którego konieczną konsekwencją jest nihilizm aksjologiczny), warto powtórzyć, że tylko założenie o wolności umożliwia stawianie pytań aksjologicznych w sensie ścisłym. Pytania takie są bowiem pytaniami o kryteria praktycznych decyzji - muszą więc zakładać wolność wyboru. Odwoływanie się do samych tylko uczuć, jak nagminnie czynią subiektywiści, tutaj nie wystarczy - bo za pomocą uczuć nie można wytłumaczyć wyboru. Kto się wszak zdaje na uczucia, ten nie wybiera - powoduje nim po prostu uczucie najsilniejsze. Gdyby wybierał, musiałby mocą zewnętrznej instancji wybrać, któremu uczuciu się podda. 
Po powyższych objaśnieniach łatwo już zgadnąć, do czego w podmiocie należy się odwołać w celu wyjaśnienia wartości. To, co je od strony podmiotu funduje, po pierwsze, nie może być ontyczną cechą podmiotu (być bytem), gdyż tłumaczenie takie popadłoby w błąd naturalistyczny. Po drugie zaś, nie mogą to być również występujące $\mathrm{w}$ podmiocie fakty psychobiologiczne, takie jak pragnienia, uczucia czy potrzeby - odwołania do nich nie tylko powielałyby bowiem ten sam błąd, ale w dodatku nie tłumaczyłyby decyzji, która przecież musi być właśnie wyborem zgody na któryś z takich faktów (wybraną zgodą na to, że moje działanie zostanie uruchomione przez pragnienie $X$, nie zaś $Y$ ). Skoro wartości określają i kierunkują wolne działania podmiotu i skoro są dla podmiotowych wyborów kryteriami, których nie można zaczerpnąć z teoretycznego poznania bytu (z zewnątrz), to ich podmiotową podstawą może być tylko sama wolność - wraz z takim swoim instrumentarium, które byłoby w stanie ustanowić kryteria słuszności dla uczuć i decyzji.

Pierwotnym materiałem dla filozofii praktycznej, w tym również dla aksjologii, jest dziedzina uczuciowych stosunków człowieka do rzeczywistości - z niej bowiem powstaje działanie praktyczne. Bez względu na to, jak tę sferę czuciowoemocjonalną byśmy teoretycznie ujmowali, dwa twierdzenia na jej temat pozostają prawdziwe: a) odczuwanie świata przez podmiot jest „pierwszym poruszycielem" ludzkiej praktyki; b) na postawie samego tylko odczuwania nie można prawomocnie stwierdzić, czy odczuwane przedmioty są dobre, czy złe. To drugie - negatywne - twierdzenie oznacza, że z faktu pozytywnego uczucia nie można wywnioskować, iż jego przedmiot jest wartościowy (i analogicznie w odniesieniu do faktu uczucia negatywnego). Z jednej więc strony, jakieś uczucie musi napędzać działanie (bez uczuć dynamizm działania jest niemożliwy), z drugiej jednak, fakt uczucia nie wskazuje wartości wytworzonego przez niego działania - pomimo że, patrząc od strony podmiotu, nie można podjąć działania bez przekonania o jego wartości. Krótko więc mówiąc, uczucia są dla wartości warunkami koniecznymi, ale niewystarczającymi.

Tak jak w sferze przekonań deskryptywnych sam fakt posiadania przekonania nie wytwarza (i nie świadczy o) prawdziwości jego treści, tak fakt, że ktoś żywi dane uczucie, nie czyni wartościowym przedmiotu tego uczucia. Przedmioty są wartościowe dopiero dzięki temu, że zwrócone na nie uczucia są słuszne lub uzasadnione. Wartości są więc konstytuowane nie przez same uczucia, lecz przez uczucia plus kryteria ich słuszności. Żeby więc wyjaśnić wartości, nie wystarczy 
- że powtórzę - odwołać się do uczuć. Trzeba koniecznie rozwiązać problem kryteriów ich słuszności.

\section{Podmiotowe źródła kryteriów wartościowania}

Ściśle biorąc, uzasadnione, i dlatego słuszne, mogą być wydawane na podstawie uczuć wartościujące sądy, nie zaś same uczucia. Wszystkie takie sądy, tzn. sądy o wartości przedmiotu wydawane na podstawie uczucia skierowanego na ten przedmiot, nazwijmy sądami emotywnymi. Nie są to sądy o uczuciach, lecz o rzeczywistości pozauczuciowej. Uczucia są ich podstawą w takim znaczeniu, w jakim podstawą sądów percepcyjnych są percepcje. Jeśli jakiś obiekt wzbudza w podmiocie jakieś uczucia - albo ma (przyczynowy lub celowościowy) związek z obiektem, który owe uczucia wzbudza - i dlatego podmiot wydaje o nim sąd wartościujący, to sąd ten jest emotywny i ma podstawę w uczuciach. Można powiedzieć zgodnie z Ch. Stevensonem, iż sądy takie wyrażają uczucia, ale zarazem przypisują obiektom cechy aksjologiczne (wartości). Z poprzedniego paragrafu wiemy, że w obiektach „samych w sobie”, jako przedmiotach ontologii, wartości nie występują, to zaś znaczy, że sądy emotywne przypisują obiektom cechy, których w nich nie ma. Pomimo to niezaprzeczalnym faktem pozostaje, że obiekty wzbudzają w podmiotach uczucia, które - po namyśle decyzyjnym (albo nawet i bez niego) - powodują działanie. Uwzględniając tę zależność działania od uczuć, wśród wyrażających je (uczucia) sądów należy odróżnić sądy emotywne i sądy praktyczne. Różnica między nimi polega na tym, że praktyczne są podzbiorem emotywnych, albowiem te pierwsze również są emotywne, tyle że są wzbogacone o dwie własności, których tamte nie posiadają. Są to mianowicie (a) własność uzasadnienia (dzięki której sądy emotywne stają się słuszne) oraz (b) własność determinowania działania praktycznego. Tę drugą własność trzeba jednak opatrzyć dwoma zastrzeżeniami. Po pierwsze, jednostkowy słuszny sąd emotywny determinuje działanie o tyle, o ile w danej sytuacji działania tego nie wykluczy (nie powstrzyma) treść innego sądu o takich samych cechach - treść, którą podmiot w tej sytuacji uzna za ważniejszą. Po drugie zaś, sądy takie determinują działanie podmiotu o tyle tylko, o ile jest on (chce być) racjonalny; jeśli racjonalny nie jest, to postępuje według sądów emotywnych (nie zaś praktycznych). 
Powyższe rozróżnienie ma też ważne konsekwencje dla pojmowania działania. Jeśli działania podmiotu są powodowane sądami emotywnymi (nieuzasadnionymi), to działania te nie są racjonalne, a w konsekwencji - nie są też wolne. Uczucia bowiem są podmiotowymi skutkami oddziaływania obiektów, a działania - w takich przypadkach - są skutkami przeżywanych uczuć: występujący tu ciąg przyczynowo-skutkowy wyklucza wolność. Jeżeli zaś działania podmiotu determinowane są przez uzasadnione (słuszne) sądy emotywne, to są działaniami wolnymi - uzasadnienie bowiem zamienia występujące tu sądy emotywne w racje, one natomiast nie są faktami, w związku z czym nie są skutkami faktów. Inaczej mówiąc, uzasadnianie sądów emotywnych jest zewnętrzną interwencją rozumu w sferę faktów uczuciowych, a rozumowe wnioskowania nie są zdeterminowane przez przyczyny - z czego wynika, że emotywne sądy, które są uzasadnione, stając się sądami racjonalnymi, są też zakorzenione w wolności.

Skoro sąd emotywny jest słuszny (czyli uzasadniony) wtedy i tylko wtedy, gdy spełnia określone kryteria, to kolejne pytanie musi dotyczyć owych kryteriów: jakie są kryteria słuszności dla sądów emotywnych (i tym samym dla „słuszności” uczuć)? Zacznijmy od tego, czym te kryteria być nie mogą. Po pierwsze, nie może do nich należeć zgodność treści uczuć z obiektem zewnętrznym. Jeśli wszak uczucia są wzbudzane przez takie obiekty, to wszystkie są w pewnym sensie zgodne ze swoimi obiektami - gdyby wszak nie były zgodne, to by nie powstały. Nie ma tu sposobu, aby stwierdzić niezgodność. Trzeba by móc (absurdalnie!) stwierdzić, że obiekt $O$ nie powinien wzbudzić uczucia $u$, a jeśli wzbudził, to uczucie to jest z nim niezgodne. Ważniejsze jednak wydaje się to, że w owej hipotetycznej zgodności musiałoby chodzić - ściśle biorąc - nie o zgodność z obiektem, lecz z jego, niezależną od podmiotu, wartością. Tymczasem zostało wcześniej ustalone, że takich obiektywnych wartości w obiektach nie ma - skoro więc nie istnieje przedmiotowy biegun relacji zgodności, to i ona sama nie może występować. Po drugie, na kryterium słuszności sądów emotywnych nie nadaje się także zgodność z uczuciami innych podmiotów (intersubiektywność uczuć). Z faktu bowiem, że wobec obiektu $O$ ktoś żywi uczucie pozytywne (i wyraża je w sądzie wartościującym) nie wynika ani to, że inni powinni takie uczucie żywić, ani to, że dotyczące tego obiektu uczucia odmienne są niesłuszne.

Po tych uwagach negatywnych można już sformułować pozytywne postulaty określające wymagane kryterium słuszności sądów emotywnych. (1) Skoro owo kryterium ma odróżniać sądy (i uczucia) słuszne od niesłusznych, to musi nim 
być coś zewnętrznego wobec rozróżnianych uczuć. (2) Skoro tym kryterium nie może być zgodność uczuć z czymś zewnętrznym - ani z obiektami, ani z uczuciami innych osób - to musi ono być wewnątrzpodmiotowe. Instancją, która spełnia oba te postulaty, jest to, od czego pochodzi uzasadnienie sądów emotywnych i co zarazem przyrodniczo zdeterminowany organizm ludzki czyni wolnym podmiotem - tą instancją jest rozum. Jego rolę w wyznaczaniu poszukiwanego kryterium trzeba jednak szerzej wyjaśnić, gdyż proste stwierdzenie, iż „kryterium słuszności sądów emotywnych jest ich zgodność z rozumem”, jest nieinformatywne, a nawet mylące.

Przede wszystkim trzeba zauważyć, że kiedy fundamentu dla sądów wartościujących i wartości szuka się w rozumie - gdy rozum ma dostarczyć ich uzasadnienia - to zawsze napotyka się na jedną podstawową trudność. Możliwości rozumu kończą się mianowicie na zapewnieniu formalnej (proceduralnej) poprawności wnioskowania praktycznego, nie jest on natomiast w stanie zapewnić prawdziwości przesłanek - nie poznaje bowiem treści wartości. Jego czysto formalny charakter pozwala wprawdzie rozstrzygać o tym, czy treść konkluzji wskazuje na wartość, czy nie, ale możliwe jest to wyłącznie wtedy, gdy treściową podstawę swoich wnioskowań (pierwszą przesłankę aksjologiczną) pozyska on spoza siebie. Rozum praktyczny operujący w dziedzinie wartości (czy też sądów wartościujących) jest co do swoich treści tym bardziej bezradny, że treściowych zasad nie może wywnioskować $\mathrm{z}$ treści sądów deskryptywnych. Jego istotowy formalizm oraz respekt dla teorii błędu naturalistycznego muszą zatem powodować, iż w procedurach uzasadniania jest on skazany na to, by treściowe podstawy uzasadnienia czerpać jednak - bo innego wyjścia bodaj nie ma - ze sfery uczuciowej. Jeśli więc idzie o kryterium słuszności dla uczuć (i sądów emotywnych), to należy stwierdzić, że na kryterium takie musi się składać dwa elementy: (1) zasady rozumu, takie jak wynikanie i niesprzeczność, są formalną stroną owego kryterium; (2) żeby zasady te były rozstrzygające dla poszczególnych sądów emotywnych, potrzebna jest jeszcze zasada treściowa, z której bądź mogłyby one wynikać, bądź być z nią niesprzeczne. $Z$ powyższych ustaleń wynika zatem, że sąd emotywny i wyrażane przez niego uczucie słuszne są wtedy i tylko wtedy, gdy ich treść albo z treściowej zasady wynika, albo jest $\mathrm{z}$ nią niesprzeczna. Ponieważ obie te relacje określa rozum, toteż zgodność z nim jest warunkiem koniecznym, acz niewystarczającym, słuszności uczuć. Warto tu przypomnieć, że uczucia słuszne wyznaczają wartości swych obiektów. 
Treściowa zasada aksjologiczna, która jest drugim, oprócz rozumu, elementem kryterium słuszności uczuć (jej drugim warunkiem koniecznym), wymaga głębszych wyjaśnień. Stoimy tu bowiem, ni mniej ni więcej, tylko przed pytaniem o źródło i treść pierwszej przesłanki dla wszelkich rozumowań aksjologicznych. Przesłanka ta musi więc wyrażać to, co absolutnie podstawowe w aksjologii, a tym samym to, co odróżnia sferę wartości od sfery bytów (lub faktów).

Skoro poszukiwana zasada aksjologiczna ma być treściową podstawą oceny wszystkich uczuć pod względem ich słuszności, to jej lokalizacja musi być związana z tym, co w podmiocie stanowi jego centrum decyzyjne. Na takie jej umiejscowienie wskazuje również to, że jej uzasadniająca i kryterialna funkcja wobec uczuć i sądów emotywnych polega na selektywnym przekształcaniu sfery tylko uczuciowej w sferę praktycznych mocy działania - emotywne sądy i uczucia, po uzasadnieniu, stają się motorami czynów. Jeśli więc dziedzina działania opiera się na uzasadnionych sądach emotywnych (na uczuciach słusznych), to treściowa zasada tego uzasadnienia - która zarazem określa praktyczne decyzje - musi być składnikiem samych podstaw podmiotowego decydowania.

Patrząc przez chwilę na tę kwestię w sposób najogólniejszy i syntetyczny, należałoby stwierdzić, iż odczuwanie i działanie są dwiema stronami praktyki - pasywną i aktywną. Przy czym odczuwanie przeistacza się w działanie o tyle, o ile przejdzie, by tak rzec, przez kontrolujący filtr rozumu - gdy rozum powie uczuciom „tak”, wtedy ich treści stają się racjami napędzającymi działanie. Żeby rozum spełniał funkcje kontrolne wobec uczuć jako napędów działania, sam nie musi dysponować własną energią - wystarczy, że jakaś część uczuć poddaje się ustalonym przez niego treściom i za ich pośrednictwem steruje całą resztą. Sterowanie to polega zaś na tym, że owe uczucia afirmujące ustalenia rozumu pełnią wobec uczuć pozostałych funkcję albo wzmacniającą (w stosunku do uczuć przez rozum afirmowanych), albo hamująco-blokującą (wobec uczuć uznanych przez rozum za niesłuszne). Na podstawie tak zarysowanej relacji między uczuciami i rozumem okazuje się, że wśród uczuć trzeba rozróżnić dwa poziomy - uczucia kontrolowane i kontrolujące. Takie ujęcie ma tę zaletę, że jest zgodne z ogólną, wcześniej eksponowaną tezą, wedle której pomimo że motorami wszelkiego działania są uczucia, to jednak nie wyklucza to udziału rozumu (i racjonalnego uzasadnienia) 
w kierowaniu działaniem. Do wyjaśnienia pozostaje jednak owa wiązka uczuć sterujących, która jest poddana rozumowi i z której zarazem on czerpie treściową podstawę swoich wnioskowań praktycznych (umożliwiających sterowanie resztą uczuć).

\section{Podmiotowe źródła pierwszej przesłanki aksjologicznej}

Objaśnienie uczuć sterujących (których liczebnie jest wprawdzie niewiele, ale są podstawowe), wymaga odwołania się do kolejnych pojęć znanych z filozofii praktycznej. Gdy szukamy podmiotowych podstaw decydowania, to dochodzimy do pytania o to, z czego składa się decydujące centrum podmiotu - czyli, jakie elementy tego centrum są konieczne do tego, żeby decydowanie było możliwe? Otóż skoro decydowanie jest wolnym wybieraniem jednej spośród kilku (lub wielu) realnych możliwości, to - pomijając same te możliwości, które dla wybierania są warunkiem przedmiotowym - podmiotowe warunki decydowania muszą być następujące.

(a) Musi wystąpić racja, która wyzwala decyzję od determinacji przez psychobiologiczne fakty - a więc w skład centrum decydującego musi wchodzić racjonalność jako rezerwuar racji i zdolność operowania nimi.

(b) Przy założeniu braku wartości w świecie (którego uzasadnienie przedstawiłem wcześniej), treść racji decydowania - nie mogąc pochodzić ani z zewnętrznego świata faktów, ani z samego rozumu - musi mieć poznawcze źródło w podmiocie. Źródłem tym jest samowiedza jako odmiana świadomości. Innymi słowy, racjonalne wnioskowania praktyczne pozyskują treści swoich racji z podmiotowej samowiedzy.

(c) Ponadto, na wszystkich swoich poziomach decydowanie wymaga jakiegoś wiodącego motywu - jakiejś chęci czy pragnienia, ze względu na które podmiot może dopiero wybierać sprzyjające im inne chęci i treści. Gdyby podmiot cechowała zupełna obojętność i o nic w jego istnieniu by mu nie chodziło, to nie miałby ani po co, ani czego wybierać. Samowiedza jest niezbędna właśnie do tego, żeby ów wiodący motyw rozpoznać i skonstatować, a następnie konstatację tę „przekazać” rozumowi jako treść przesłanki dla rozumowań praktycznych. Wszystko to znaczy, jak wyraźnie widać, że bez tego wiodącego motywu w życiu podmiotu nie mogłyby wystąpić żadne wartości, albowiem ani samowiedza, ani 
rozum nie miałyby przesłanek dla racji praktycznych, które - jak wcześniej stwierdziłem - ustanawiają wartości obiektów. Wymagająca wyjaśnienia wiązka uczuć sterujących jest, oczywiście, niczym innym niż wymieniony właśnie wiodący motyw.

Żeby treść tego motywu mogła być przesłanką dla wszystkich racji praktycznych (nie zaś tylko dla wąskiego ich rejonu) - wszak tylko wtedy może on spełniać funkcje sterujące życiem podmiotu - tworzące go uczucia i pragnienia muszą mieć charakter ze wszech miar fundamentalny. Ich treść dostarcza bowiem pierwszej przesłanki dla rozmaitych szeregów wnioskowań praktycznych, a także dla rozstrzygania tego, które konkluzje tych szeregów powinny być preferowane (a więc dla porównywania różnych wartości). Przedstawienie pełnej teorii tego wiodącego motywu wymagałoby osobnego opracowania. W tym miejscu jestem zmuszony ograniczyć się do maksymalnie skrótowej jego charakterystyki, eksponującej tylko najważniejsze jego atrybuty.

Do tego, co nazwałem „wiązką uczuć sterujących”, a w drugim kontekście określiłem „motywem wiodącym”, można zapewne stosować różne pojęcia (z czym mamy faktycznie do czynienia w różnych teoriach psychologicznych), sądzę jednak, że wystarczające jest tradycyjne pojęcie szczęścia. W potocznym użyciu pojęcie to jest wprawdzie nader wieloznaczne, ale w nawiązaniu do znanych konceptualizacji filozoficznych można je sprecyzować. Wiadomo, że w różnych ujęciach szczęścia powtarza się określenie, wedle którego jest ono „zadowoleniem z całości życia”10. W obecnym kontekście szczęście interesuje nas jako ten element życia podmiotu, który, poprzez dostarczenie treściowego kryterium dla słuszności sądów emotywnych, objaśniałby konstytuowanie się wartości. Ze względu na tę kwestię spośród wielu aspektów szczęścia trzeba wyeksponować tylko te, które są przydatne do jej wyjaśnienia. Zacznijmy zatem od owej „całości życia”, która jest podstawą obecnego w szczęściu zadowolenia. By możliwa była zadowoleniowa reakcja na tę całość, muszą być spełnione pewne warunki.

Po pierwsze, całość ta musi być jakoś podmiotowi dana. Ponieważ wiadomo, że nie jest dana w obecnym doświadczeniu, to musi być dana jako treść myślenia, a właściwie - jako treść samowiedzy. Z tego faktu wynikają na temat szczęścia co najmniej dwa ważne wnioski. Pierwszy mówi o tym, że szczęście występuje tylko u bytów zdolnych do samowiedzy. Drugi zaś orzeka, że szczęście jako zadowolenie

${ }^{10}$ Por. Władysław Tatarkiewicz, O szczęściu (Warszawa: PWN, 1985), 30-42; por. też Robert Spaemann, Szczęście i życzliwość, tłum. Jarosław Merecki (Lublin: RW KUL, 1997), 86-87. 
nie jest uczuciową reakcją na pojedyncze bodźce lub przeżycia, lecz reakcją na treść myślenia ujmującego pewną całość. To natomiast znaczy, że szczęście nie jest jednym z wielu spontanicznych uczuć wzbudzanych przez jakieś konkretne obiekty, lecz że jego koniecznym składnikiem jest refleksyjny namysł i myślowy bilans, których przedmiotami są tamte uczucia. To z kolei prowadzi do wniosku, iż „szczęście” jest pojęciem w najwyższym stopniu syntetycznym oraz refleksyjnym - żeby skonstatować szczęście, trzeba myślowo zjednoczyć całą wielość swoich przeżyć, a to jest możliwe tylko w refleksji. Ponieważ stwierdzanie własnego szczęścia jest dokonaniem refleksji (nie jest raportem z empirycznego przeżycia), to nie może być traktowane jako zdeterminowane przyczynowo - stwierdzenie to jest aktem wolności podobnym do aktów, które w teorii ustalają końcowe wnioski. Z powyższych uwag wynika, że jeśli nawet obecne w szczęściu zadowolenie jest w ogóle uczuciem, to uczuciem nader osobliwym - takim mianowicie, które: (a) występuje wyłącznie po uprzedniej refleksji; (b) wobec wszystkich innych uczuć ma pozycję zwierzchnią (jest ostatecznym punktem odniesienia dla świadomego zarządzania resztą uczuć); (c) samo jest ostateczną jednością, ustanowioną przez refleksyjny i syntetyzujący namysł nad wielością uczuć pozostałych - nie jest wymienialną i instrumentalizowalną częścią życia uczuciowego, lecz jednoczącą je zasadą. Takie cechy szczęścia sytuują je w podmiocie na pozycji, która jest instancją oceniającą i selekcjonującą, ale sama nie podlega ani ocenie, ani alternatywnym wyborom - podmiot nie może wybrać czegoś innego niż szczęście, gdyż w uzasadnieniu takiego wyboru musiałby popaść w błędne koło (coś innego niż szczęście wybrałby bowiem dla szczęścia, albo w ogóle nie byłby to wybór). Co do podkreślanej tu funkcji jednoczenia pewnej podmiotowej wielości (mianowicie: uczuciowej), szczęście ma status podobny do samej jaźni, czy też jakkolwiek inaczej nazywanej zasady, nadającej podmiotowi jednoczącą go tożsamość.

Drugi szereg warunków, które umożliwiają „zadowolenie z całości” (czyli szczęście) wiąże się z faktem, iż całość o tyle tylko jest całością, o ile posiada zasadę jedności. Mówiąc krótko, każda całość musi mieć coś, co ją jednoczy. Żeby więc podmiot mógł pomyśleć swoje życie jako całość, musi siebie samego ujmować myślowo i traktować praktycznie jako jedność - nie zaś jako strumień czy wiązka osobnych przeżyć. Znaczy to, że jeśli ktoś chce być zadowolony z całości swego życia (szczęśliwy), musi założyć, że jest (lub musi chcieć być) podmiotem czasowo identycznym. Można więc stwierdzić, że pojęcie szczęścia - jako syntetycznego, 
jednego zadowolenia z wielu szczegółowych zadowoleń wchodzących w skład całości życia - jest wymuszone przez, trudne do odrzucenia, założenie o jedności podmiotu: jeśli podmiot, oprócz wielości przeżyć, ma w sobie także jedność, to również, oprócz wielu zadowoleń i przykrości, musi on posiadać jakieś jedno, rzec by można, metazadowolenie.

Wykazywany tu syntetyczny i scalający wielość uczuć charakter szczęścia ma szczególne znaczenie dla filozofii praktycznej i realnej praktyki podmiotu. Myślenie praktyczne, jak wiadomo, nie polega na konstatowaniu tego, co jest i było, lecz jest - wychodzącym z punktu wolności - projektowaniem pożądanych stanów rzeczy („pożądanych” znaczy tu na razie zarówno upragnionych, jak i powinnych). Otóż jeżeli podmiot racjonalnie myśli o swoim przyszłym działaniu, czyli jeśli nie poddaje się bezwiednie grze wzbudzanych uczuć, lecz uzasadnia samemu sobie, dlaczego należy zrobić to, a nie co innego, to szczęście staje się dla niego wspomnianym, podstawowym motywem wiodącym, którego treść pełni rolę pierwszej przesłanki aksjologicznej $\mathrm{w}$ jego wartościujących rozumowaniach. Uczucia i zdarzenia, które go pociągają, jak również spodziewane przeżycia przykre, bilansuje on w taki sposób, żeby zarządzanie nimi dało mu w efekcie projektowany stan szczęścia (albo podtrzymanie stanu obecnego, albo - jeśli to możliwe - podwyższenie go). Zarówno bez idei szczęścia, jak i bez tego racjonalnego bilansowania, nie mógłby on dokonywać wiążących wyborów. Bez pierwszej - nie miałby dla nich treściowej przesłanki. Bez drugiego zaś - nie potrafiłby tej pierwszej przesłanki poprawnie uszczegółowić (przez co byłby skazany na spontaniczny automatyzm każdorazowych uczuć). Nie mogąc swoim działaniem racjonalnie zarządzać, w istocie nie byłby tego działania podmiotem. W ten sposób jeszcze raz się okazuje, że do ukonstytuowania się podmiotu praktyki konieczna jest zarówno racjonalność praktyczna, jak i idea jednocząca treściowo całożyciowy „zysk” podmiotu, czerpany z faktu uczestnictwa w rzeczywistości - ta druga jest, oczywiście, ideą szczęścia.

Warto powtórnie podkreślić, że powyższe wyjaśnienia są konstruowane jako ujęcie działania praktycznego alternatywne zarówno wobec koncepcji aksjologicznego obiektywizmu, jak i subiektywizmu. Do wysuniętych już wcześniej zarzutów wobec obu tych koncepcji, obecnie można dodać kolejny. Praktyka ludzka widziana w świetle subiektywizmu aksjologicznego musi być pozbawiona podmiotu - rozpada się on bowiem na wielość empirycznych pragnień, niezależnych w dodatku od racjonalności (ale podległych determinacji przyczynowej). Jeśli zaś 
idzie o aksjologiczny obiektywizm, to wprawdzie podmiot może działać z założeniem o jego trafności, ale trzeba niestety zauważyć, że gdyby wartości rzeczywiście były od podmiotu niezależne (jak obiektywizm utrzymuje), to podmiot nie mógłby ich wybierać, lecz jedynie, wraz z ich poznaniem, automatycznie im się poddawać - co także kwestionuje jego podmiotowość wobec nich. Wedle zaś proponowanego tutaj eudajmonizmu, podmiot, owszem, może mieć duże trudności z ustaleniem treściowych warunków swojego szczęścia (czyli z nabywaniem samowiedzy), jak również może mieć różnego stopnia trudności z respektowaniem racjonalności praktycznej w swoich decyzjach (może być w życiu mniej lub bardziej racjonalny), nie są to jednak wady teorii działania, lecz praktyczne trudy i zmagania, jakie musi podjąć każdy człowiek, żeby jego życie miało charakter podmiotowy.

Po zarysowanej krótko charakterystyce formalnych aspektów szczęścia ${ }^{11}$ można już podsumować kwestię kryteriów słuszności sądów emotywnych (i uczuć). Na kryteria te składają się - jak już wspomniałem - dwa elementy: (a) logiczna poprawność wnioskowań praktycznych (przebiegających od podstawowej przesłanki aksjologicznej do szczegółowych, również aksjologicznych, wniosków) oraz (b) zgodność treści owych sądów szczegółowych z treścią przesłanki podstawowej. Objaśniając punkt (b) należy dodać, że treścią przesłanki podstawowej jest pojęcie „szczęścia” odnoszące się do szczęścia danego podmiotu, zaś wymagana zgodność nie jest implikacją, lecz niesprzecznością. Na przykład sąd, że kogoś uszczęśliwia życie małżeńskie, nie implikuje tego, z kim powinien się on ożenić - brak małżeństwa będzie jednak sprzeczny z tym sądem (ergo: będzie pozbawiony wartości), zaś ożenek z dowolną osobą $X$, będzie z nim niesprzeczny i dlatego - przy braku kontrargumentów szczegółowych - wartościowy. Zastosowanie wymienionych kryteriów do występujących w praktyce uczuć i sądów emotywnych przybiera zatem schemat następujący: jeśli treść uczucia $u$ (i opartego na nim sądu emotywnego) jest niesprzeczna z tym, co dany podmiot uszczęśliwia ( $z$ treścią jego szczęścia), to (a) takie uczucie i taki sąd emotywny

${ }^{11} \mathrm{~W}$ dokładniejszej teorii szczęścia należałoby odróżnić jego aspekty formalne od aspektów treściowych. Te pierwsze określają, czym szczęście jest i stosują się do wszystkich podmiotów (są uniwersalne), aspekty treściowe natomiast określają to, co kogo w jakim stopniu uszczęśliwia, poznawane są przez indywidualną samowiedzę i są częściowo (a niekiedy znacznie) zróżnicowane w odniesieniu do indywidualnych podmiotów. 
są słuszne, a w konsekwencji (b) obiekt, do którego owa treść się odnosi, jest wartościowy. Wynika z tego, jak już wcześniej sugerowałem, że wartości obiektów nie są obiektywnymi ich własnościami, lecz są funkcjami zwróconych ku nim przez podmiot uczuć słusznych (w przedstawionym sensie). Od strony negatywnej znaczy to, że jeśli treść jakiegoś pozytywnego uczucia (i sądu emotywnego) jest niezgodna lub neutralna wobec szczęścia podmiotu, to takie uczucie i sąd są niesłuszne, a ich przedmiot nie jest wartościowy. W dziedzinie uczuć i sądów emotywnych możliwe są więc złudzenia i błędy, które powstają wtedy, gdy podmiot wykazuje albo niedostatek samowiedzy (nie wie, co go uszczęśliwia), albo deficyt racjonalności praktycznej (wprawdzie wie, co go uszczęśliwia, ale nie potrafi ustalić logicznych i empirycznych powiązań między treścią przygodnego uczucia a treścią szczęścia).

Warto zaznaczyć, że nie wszystkie - ustalane w powyższy sposób - wartości obiektów należy realizować w działaniu. Innymi słowy, z tego, że obiekt jest wartościowy, nie wynika, że tu i teraz powinienem wykonywać jakieś zmierzające do niego działania. Zawsze bowiem działanie wymagane przez inny obiekt słusznego uczucia może okazać się albo ważniejsze, albo bardziej pilne. Pomimo więc, że słuszna jest reguła, wedle której każdy obiekt słusznego uczucia (każdy wartościowy) jest dla podmiotu powinnością, to jednak w całym zbiorze tych powinności ogólnych trzeba rozróżnić poszczególne klasy powinności, kierując się (a) kryterium stopnia ważności (jedne powinności są ważniejsze od innych) oraz (b) kryterium pilności (pomimo że jedne powinności są ważniejsze, to jednak, jeśli mniej ważne są bardziej pilne i zarazem nie pogwałcają ważniejszych, powinno się w danej sytuacji spełniać te pilne). Sygnalizując potrzebę klasyfikacji różnych powinności, a także potrzebę opracowania racjonalnych zasad, które określałyby ich praktyczne preferowanie, kwestię tę odkładam do osobnej analizy ${ }^{12}$.

Dodatkowych wyjaśnień wymaga jeszcze sposób przekształcania się deskryptywnej samowiedzy dotyczącej szczęścia w podstawową przesłankę rozumowań rozstrzygających o słuszności szczegółowych sądów emotywnych - przesłanka ta musi bowiem mieć charakter aksjologiczny. Jako pewien stopień zado-

${ }^{12}$ Warto zauważyć, że w interesujący sposób kwestię rodzajów powinności opracował N. Hartmann; por. Nicolai Hartmann, „Stosunek wartości i powinności”, w: $Z$ fenomenologii wartości, 101- 109; por. też Leszek Kopciuch, Wolność a wartości. Max Scheler, Nicolai Hartmann, Dietrich von Hildebrand, Hans Reiner (Lublin: Wydawnictwo UMCS, 2010), 64-71. 
wolenia z całości życia szczęście jest czymś, co podmiot zarówno aktualnie posiada, jak i tym, czego - w projektowaniu swojej przyszłości - chce i co spodziewa się utrzymać, a nawet w miarę możliwości zmaksymalizować. Można powiedzieć, że jest ono celem wszystkich celów, a raczej podstawą umożliwiającą i integrującą wszystkie cele - bez dążenia do szczęścia podmiot nie miałby bowiem (a) ostatecznej racji dla jakiegokolwiek celu, ani też (b) nie miałby podstawy dla wybierania celów. Gdyby zaś nie miał ani racji wyborów, ani treściowego ich kryterium, to jego funkcjonowanie nie zawierałoby $\mathrm{w}$ istocie decyzji, lecz musiałoby być zdeterminowane empirycznymi przyczynami. Pytanie o przekształcenie faktu szczęścia w normatywny fundament sfery aksjologicznej jest więc pytaniem o to, jak w ludzkiej świadomości synteza pasywnego odczuwania przekształca się w równie syntetyczną podstawę aktywności. W obu przypadkach syntezy dokonuje samowiedza. Gdyby człowiek nie dysponował samowiedzą, to zarówno jego odczuwanie, jak i jego działanie rozpadałoby się na wiele sytuacyjnych odczuć i motywów - nie mając wtedy całości życia, szczęścia ani by nie stwierdzał, ani nie projektował. Żeby synteza odczuć przekształciła się w syntezę projektu, wobec tej pierwszej podmiot musi podjąć wolną decyzję afirmatywną, która z tego, co jest, uczyni treść dążenia skierowanego ku przyszłości - a mówiąc dokładniej, która ze szczęścia aktualnego uczyni pewien dynamiczny (z tendencją do maksymalizacji) wzorzec dla chcianej syntezy, wyznaczającej wszystkie cele. Ujmując to najprościej, tym, co przekształca konstatację w projekt, jest wolna decyzja, afirmująca treść konstatacji.

Decyzję, o której mowa - określając ją jako pradecyzję - charakteryzowałem dokładniej w innych pracach ${ }^{13}$; tutaj ograniczę się więc do kilku niezbędnych uwag na jej temat. Nazywam ją pradecyzją, ponieważ, chociaż rzadko jest podejmowana w sensie psychologicznym (chyba tylko w sytuacjach granicznych), to jednak - jako ostateczne uzasadnienie transcendentalne - jest ona zakładana, czy też współpodejmowana, wraz z każdą decyzją codzienną. W porządku uzasadnienia każda „zwykła” decyzja odsyła do innej, bardziej podstawowej, ale gdy ktoś zechce uzasadnić całość tego szeregu (gdy spyta siebie, po co w ogóle podejmuje wszystkie decyzje), to musi odwołać się do decyzji logicznie pierwszej, której nie poprzedza już żadna decyzja, lecz jedynie osiągana w rozwoju osobniczym zdolność do wolnych decyzji. Pradecyzja jest więc koniecznym warunkiem wszystkich

${ }^{13}$ Szczególnie por. Andrzej Niemczuk, Traktat o złu (Lublin: Wydawnictwo UMCS, 2013), 85111. 
decyzji: żebym mógł jutro podejmować decyzje, muszę dzisiaj zdecydować, że wybieram sposób istnienia wolnego podmiotu - a nawet, żeby moja najdrobniejsza decyzja miała ufundowanie w racjach (inaczej wszak nie byłaby decyzją), musi też mieć ufundowanie w pierwszej racji, której dostarcza dopiero pradecyzja. Każda bowiem decyzja (identyfikowanie jej jako decyzji) ma założone w sobie pewne konieczne atrybuty jej podmiotu. Jest to przede wszystkim wolność podmiotu, ale nie mnie konieczne jest też posiadanie przez niego aksjologicznych racji, a tym samym - racjonalności praktycznej. Jeśli wolność podmiotu jest koniecznym złożeniem każdej decyzji, to musi ona także być źródłem faktu, iż kontynuuje on własne istnienie, nie zaś je porzuca. Jeżeli zatem pradecyzja rozstrzyga o tym, że podmiot aktywnie trwa, i jeżeli aktywne trwanie oznacza w jego przypadku podejmowanie racjonalnych decyzji (inaczej nie trwałby jako podmiot), to prowadzi to te $\dot{z}$ do wniosku, iż w pradecyzji wybiera on nie tylko własne istnienie, ale także bycie racjonalnym. Gdyby zresztą wybrał istnienie, a nie wybrał racjonalności, to owo istnienie nie byłoby jego własnym - wszak bez prowadzenia swego życia za pomocą racjonalnych decyzji byłby on jedynie modyfikowanym przyczynowo następstwem stanów psychofizycznych.

Jeśli więc idzie o treść pradecyzji, to pomimo że jest ona jedna, ma kilka aspektów. Jedność jej treści nadaje występująca w niej afirmacja istnienia - w pradecyzji bowiem podmiot wybiera przede wszystkim istnienie (a neguje i dezaprobuje nieistnienie). Wyrażona w sądzie treść takiego wyboru jest następująca: „istnienie jest aksjologiczną pozytywnością, nieistnienie zaś - aksjologiczną negatywnością". Nawiasem mówiąc, przedstawiony sąd (będący funkcją pradecyzji podmiotu) jest absolutnie pierwszym twierdzeniem aksjologii - i ono dopiero, logicznie rzecz biorąc, pozwala aksjologię nabudowywać na ontologii. Samo istnienie jest jednak beztreściowe. Afirmując istnienie, podmiot musi więc afirmować istnienie czegoś(lub istnienie występujące $w$ czymś istniejącym). Oczywiście, przedmiotem jego afirmacji jest istnienie jego samego jako podmiotu - co oznacza, że pradecyzja jest przede wszystkim podmiotowym aktem autoafirmacji. Gdy jednak, po tych wstępnych wyjaśnieniach, zechcemy wyartykułować pełną treść owej autoafirmacji, to dalej już musimy wymieniać aspekty tego, co jest afirmowane - a są nimi w zasadzie wszystkie atrybuty, składające się na istnienie podmiotu (bycie podmiotem $)^{14}$. Nie siląc się na osiągnięcie ich zupełności, wymienię tylko

\footnotetext{
${ }^{14}$ Atrybuty podmiotu dokładniej charakteryzowałem w: Andrzej Niemczuk, Podmiot $w$ filozofii praktycznej (Rzeszów: Wydawnictwo Uniwersytetu Rzeszowskiego, 2018).
} 
te, które są potrzebne do wytłumaczenia wartości. Są to niewątpliwie: wolność, samowiedza, racjonalność praktyczna - no i uposażenie psychofizyczne podmiotu, a szczególnie zdolność odczuwania. Gdy zatem podmiot decyduje się kontynuować własne istnienie, to znaczy to, że projektuje on w przyszłość afirmację tych swoich atrybutów, które czynią go podmiotem. Co więcej, ponieważ idzie o jego istnienie własne, toteż afirmacja ta dotyczy również zachowywania tożsamości. Skoro zaś afirmowana w pradecyzji treść posiada tych kilka aspektów, to i od strony afirmujących aktów należy mówić o kilku uczuciach (można je nazwać egzystencjalnymi) - dlatego właśnie wspominałem wcześniej o „wiązce uczuć podstawowych", których treść stanowi kryterium oceny uczuć pozostałych. Pozytywna pradecyzja podmiotu oznacza więc zgodę rozumu nie tylko na uczuciową aprobatę samego istnienia, ale zawiera w sobie również uczuciową afirmację wolności, racjonalności, własnej tożsamości itp. Kiedy więc w życiowej praktyce podmiot ulega uczuciu, którego treść jest niezgodna z jego aprobatą rozumu, to jego działanie pogwałca wtedy treść jego pradecyzji - to zaś znaczy, że zarówno to jednostkowe uczucie, jak i powodowane nim działanie są niesłuszne.

Z powyższych stwierdzeń wynika, że pradecyzja, konstytuując aksjologiczny charakter istnienia, tworzy fundament dla wartości obiektów istniejących oraz - ustalając pierwszą przesłankę aksjologiczną - dla rozumowań praktycznych, które rozstrzygają o stopniu wartości poszczególnych obiektów. Nie wchodząc w szczegółowe zależności, jakie rządzą racjonalnością praktyczną ${ }^{15}$, wymienię tylko jedną jej regułę, przydatną do objaśnienia samej pradecyzji. Jest ona następująca: skoro podjąłeś pradecyzję (uznałeś swoje istnienie za cenne), to wartościowy i godny działania jest każdy obiekt twojego pozytywnego uczucia, $o$ ile nie istnieją żadne praktyczne racje przeciwko niemu. Reguła ta oznacza, że jeśli nie istnieją poprawne argumenty, które by zabraniały realizować w praktyce dane uczucie, to wtedy (ale wyłącznie wtedy!) ono samo jest racją wartości swojego obiektu oraz racją działania.

Jeśli zastosujemy tę regułę do pradecyzji, to okaże się, że szczęście czerpane $\mathrm{z}$ faktu istnienia tylko wtedy nie mogłoby być racją cenności istnienia, gdyby istniały jakieś racje praktyczne, kwestionujące miarodajność szczęścia w tym względzie. Otóż dla podmiotu uszczęśliwianego swoim istnieniem racje kwestionujące cenność tego istnienia nie tylko faktycznie nie istnieją, ale nawet istnieć nie mogą.

${ }^{15}$ Por. mój artykuł „Practical Rationality - its Nature and Operation”, Studia Humana 8, nr 2 (2019), w druku. 
I dlatego szczęście jest racją pradecyzji - treść pradecyzji stanowi natomiast absolutnie pierwszą przesłankę dla praktycznych rozumowań, które - w przedstawiony już sposób - konstytuują wartości obiektów uczuciowych.

\section{Normatywność wartości, które nie istnieją}

Ani sama pradecyzja, ani decyzje poszczególne (ani także rozumowania praktyczne) nie dodają niczego ontycznego do obiektów uznawanych za wartościowe. Obiekty te, zarówno przed ludzkim wartościowaniem, jak i po nim, pozostają tym, czym ontycznie są (tzn. nie posiadają dodatkowych cech zwanych wartościami) - i dlatego ontologia, która, będąc filozofią teoretyczną, abstrahuje od pradecyzji, nie może w nich żadnych wartości dostrzec. Wartości istniejących obiektów polegają na tym, że stosownie do struktury podmiotu obiekty te najpierw umożliwiają jego istnienie, a następnie - na różne sposoby i w różnym stopniu - składają się na jego, czerpane z faktu istnienia szczęście. Źródłem wszystkich wartości w świecie jest zaś podejmowana i utrzymywana przez wolną pradecyzję autoafirmacja podmiotu. Jeśli tej autoafirmacji zabraknie, to w realnym życiu świat traci wszystkie wartości (nie tracąc istnienia), w aksjologii zaś (czyli w teorii) brakuje wtedy racji dla uzasadnienia jakichkolwiek sądów wartościujących. Słowem, tajemnica wartości tkwi w podmiocie.

Owa podmiotowa autoafirmacja jest też kluczem do zrozumienia fenomenu normatywności (czy też obowiązywania). Normatywność obowiązuje tylko tych ludzi, którzy, chcąc być podmiotami, aprobują także racjonalność jako jeden z koniecznych atrybutów podmiotowości. Znaczy to, po pierwsze, że bycie w zgodzie z racjonalnością dla takich ludzi, czyli dla podmiotów, jest niezbędnym składnikiem szczęścia - z czego z kolei wynika, że nie mogą oni być szczęśliwi bez respektowania wartości ${ }^{16}$. Po drugie, negatywna strona tego faktu jest następująca: pomimo że w myśleniu ludzi ignorujących racjonalność kategoria powinności nie występuje (jest zredukowana do kategorii tego, co pożądane), to jednak inne podmioty „nakładają” na nich powinności, gdyż inaczej nie mogłyby traktować ich jako podmioty - od ludzi nieracjonalnych inni wymagają, pod presją kooperacji

${ }^{16}$ Ta teza odróżnia zasadniczo broniony tu eudajmonizm od hedonizmu. 
społecznej, aby byli racjonalni. Dalszych implikacji powyższych stwierdzeń - pokazujących, że ludzie z gruntu nieracjonalni nie są podmiotami - nie będę tu rozwijał, gdyż są one oczywiste na podstawie całego wcześniejszego wywodu.

W całej sferze normatywności obowiązuje zasada następująca: powinienem $Y$ wtedy i tylko wtedy, gdy chcę $X$, a $Y$ jest racjonalną konsekwencją $X$-a. Innymi słowy, „powinność” nie wynika ani z wartości (bo jest odwrotnie), ani z możliwości (bo z niej nie wynika nic aksjologicznego), lecz z „chcę” (z „on chce” nie wynika, bo $z$ faktu nie wynika nic aksjologicznego). Jeśli niczego nie chcę, łącznie z własnym życiem (!), to niczego nie powinienem. „Powinność” dlatego wynika $\mathrm{z}$ „chcę”, że chcenie jest pragnieniem racjonalnym, a powinność jest kategorią racjonalności (poza sferą racjonalności powinność nie występuje). Status powyższej zasady jest ściśle analogiczny do statusu zasady racji dostatecznej. Jak zasada racji (pomimo że jest niedowodliwa) stanowi konieczny warunek wyjaśniania czegokolwiek, tak zasada, o której mowa, jest koniecznym warunkiem możliwości uzasadniania powinności (racjonalnego dyskursu o powinności). Jeśli ktoś tej zasady nie zaakceptuje, to odbierze sobie możliwość poprawnego uzasadnienia powinności - pozostanie mu albo wywodzenie powinności z faktów (nielogiczne), albo bałamutność intuicjonizmu i mistycyzm wartości obiektywnych. Warto podkreślić, że sformułowana tu zasada pozwala na to, a nawet wymaga, żeby - pomimo nieistnienia wartości - w sferze normatywności stosować racjonalną argumentację (wbrew emotywistom). Na jej podstawie można zarówno uzasadniać powinności pozytywne, jak i w wiążący sposób wykazywać ich pogwałcanie. W mojej argumentacji zasadę tę wypełnia treść twierdzenia o pradecyzji jako o absolutnie pierwotnym „chcę", ustanawiającym pierwszą treściową przesłankę dla rozumowań normatywnych.

Jeśli idzie o najogólniejsze rodzaje powinności, to całą dziedzinę normatywną trzeba podzielić na dwie sfery: sferę powinności międzypodmiotowych oraz sferę powinności wewnątrzpodmiotowych. Te pierwsze tworzą moralność, a ich normatywność jest uniwersalna i intersubiektywna - co moralnie obowiązuje jednego wobec innych, to samo wobec innych obowiązuje każdego. Powinności ze sfery drugiej natomiast, jako pozamoralne i zindywidualizowane, są różne dla różnych podmiotów - można powiedzieć, że obowiązują subiektywnie. Na przykład poetę obowiązuje tworzenie poezji, rolnika dbałość o plony, a sportowca systematyczny trening - powinności tych nie można jednak wobec wymienionych podmiotów zasadnie zamienić. 
Przedstawiony podział powinności wymaga, oczywiście, szczegółowego rozwinięcia, na które nie ma tu miejsca ${ }^{17}$. Wskazuję na niego tylko po to, żeby wykluczyć ewentualną dezinterpretację proponowanych tu twierdzeń. Idzie mianowicie o to, że z twierdzenia, iż wartości nie istnieją, lecz są wyznaczane przez pradecyzję podmiotu, wcale nie wynika - jak mogłoby się wydawać - ani relatywizm w etyce, ani pochwała jakiegoś anarchicznego emocjonalizmu w prywatnym życiu praktycznym. Nie wynikają one dlatego, że pradecyzja jest - między innymi - afirmacją racjonalności, ona zaś nie jest ani relatywna, ani anarchiczna. Jeśli dla podmiotu aprobowanie racjonalność jest tym samym, co jego „być albo nie być” - a to właśnie wynika z moich twierdzeń - to w jego wewnętrznej strukturze racjonalność staje się powinnością dla jego uwarunkowanej przyczynowo spontaniczności psychicznej. Tym samym też respektowanie racjonalności, a to znaczy, ocenianie i porządkowanie w jej świetle własnych uczuć, jest dla niego obowiązkiem - zarówno w praktyce interpersonalnej (moralnej), jak i w życiu ściśle indywidualnym. W obu tych sferach występuje więc dualizm tego co racjonalne (a więc wartościowe) i tego, co nieracjonalne i dlatego - w perspektywie treści pradecyzji - szkodliwe lub złe. Stanowisko takie nie oznacza przy tym bynajmniej radykalnego racjonalizmu deprecjonującego sferę uczuciową (co najczęściej zarzucano etyce Kantowskiej). Wartościowanie racjonalne od nieracjonalnego nie różni się bowiem brakiem uczuć - oba są wszak uczuciowe. Tyle że w przypadku wartościowania racjonalnego - jako uczuciowości poddanej kryterium racjonalności - uczucia są ze sobą zharmonizowane przez refleksyjną interwencję rozumu (treść jednego uczucia nie przeczy treści drugiego). Proponowany tu wymóg racjonalnego namysłu nad własną uczuciowością (głęboko zgodny z etyką Arystotelesa) trafniej jest identyfikować z wymogiem roztropności (czy praktycznej mądrości) niż z jakimś jednostronnym, kostycznym racjonalizmem.

Jeśli w proponowanej tu konceptualizacji działania i wartości ktoś chciałby doszukiwać się miejsca, w którym mogłaby wystąpić arbitralność, to miejscem takim jest ewentualnie sama pradecyzja. Nie jest ona wprawdzie jedynym aktem wolności, ale od pozostałych różni się tym, że one mogą być oparte na zewnętrznym kryterium słuszności, ona zaś - jako że kryterium to dopiero ustanawia - za

${ }^{17}$ Problem powinności moralnych analizowałem szerzej w: „Aksjologiczne uzasadnienie etyki”, w: Andrzej Niemczuk, Filozofia praktyczna. Studia i szkice (Lublin: Wydawnictwo UMCS, 2016), 239269; oraz w: Traktat o złu, 184-208. 
swoją podstawę ma jedynie (a) konstatację odczuwanego szczęścia oraz (b) świadomość braku argumentów przeciwko niej. Nawet jeśli - w związku z powyższym - można ją nazwać decyzją arbitralną (co, zważywszy na „rację” szczęścia, jest wątpliwe), to na taki zarzut można z całą powagą odpowiedzieć, że w niczym nie zagraża to ani racjonalności, ani morale wśród podmiotów żyjących.

\section{Bibliografia}

Buczyńska-Garewicz, Hanna. Uczucia i rozum w świecie wartości. Wrocław: Wydawnictwo PAN, 1975.

Findlay, John Niemeyer. Meinong's Theory of Objects and Values. Oxford: Clarendon Press, 1963.

Hartmann, Nicolai. $O$ idealnej samoistności wartości. W: $Z$ fenomenologii wartości. Tłum. i red. Włodzimierz Galewicz, 85 -101. Kraków: PAT, 1988.

Hartmann, Nicolai. Stosunek wartości i powinności. W: Z fenomenologii wartości. Tłum. i red. Włodzimierz Galewicz, 101-109. Kraków: PAT, 1998.

Hartmann, Nicolai. Systematyczna autoprezentacja. W: Nicolai Hartmann, Myśl filozoficzna i jej historia. Systematyczna autoprezentacja, 73-134. Tłum. Jan Garewicz. Toruń: Wydawnictwo Comer, 1994.

Hołówka, Jacek. Relatywizm etyczny. Warszawa: PWN, 1981.

Kopciuch, Leszek. Wolność a wartości. Max Scheler, Nicolai Hartmann, Dietrich von Hildebrand, Hans Reiner. Lublin: Wydawnictwo UMCS, 2010.

Niemczuk, Andrzej. „Aksjologiczne uzasadnienie etyki”. W: Andrzej Niemczuk, Filozofia praktyczna. Studia i szkice, 239-269. Lublin: Wydawnictwo UMCS, 2016.

Niemczuk, Andrzej. Podmiot w filozofii praktycznej. Rzeszów: Wydawnictwo Uniwersytetu Rzeszowskiego, 2018.

Niemczuk, Andrzej. „Practical Rationality - its Nature and Operation”, Studia Humana 8, nr 2 (2019), w druku.

Niemczuk, Andrzej. Stosunek bytu do wartości. Dociekania metafizyczne. Lublin: Wydawnictwo UMCS, 2005.

Niemczuk, Andrzej. Traktat o złu. Wydawnictwo UMCS, Lublin 2013.

Rickert, Henrich. „Sens i wartośç" W: Neokantyzm, wstęp i wybór tekstów Beata TrochimskaKubacka, tłum. Beata Trochimska-Kubacka i Janina Gajda-Krynicka, 111-120. Wrocław: Wydawnictwo Uniwersytetu Wrocławskiego, 1997.

Rickert, Heinrich. „Tezy do systemu filozofii”. Tłum. Beata Borowicz-Sierocka. W: Neokantyzm, red. Beata Borowicz-Sierocka, Czesław Karkowski, 45-54. Wrocław: Wydawnictwo Uniwersytetu Wrocławskiego, Wrocław 1984. 
Schnädelbach, Herbert. Filozofia w Niemczech 1831-1933. Tłum. Krystyna Krzemieniowa. Warszawa: Wydawnictwo Naukowe PWN, 1992.

Spaemann, Robert. Szczęście i życzliwość. Tłum. Jarosław Merecki. Lublin: RW KUL, 1997. Tatarkiewicz, Władysław. O szczęściu. Warszawa: PWN, 1985.

\section{Summary}

\section{On non-existence and normativity of values}

The main purpose of the paper is to prove that values do not belong to the concept of being and that they are obligatorily attached to the subject, even though they do not exist objectively. The author censures the ontology of value. Presented are arguments in support of positive theses that: (1) valuable objects are subjects of correct feelings; (2) lack of inconsistency between the substance of feelings and the subject's happiness as indicated by self-knowledge and reason, evidences correctness of feelings; (3) the content of happiness, affirmed by free decision (pre-decision) represents the content of the first axiological premise in practical reasoning; (4) it is human desire of being the subject affirming one's own freedom and rationality that represents the source of normativity of values. The axiological position proposed by the author is placed between two censured extremes, that is objectivist ontology of values and subjectivistic emotivism.

Keywords: values, normativity, happiness

\section{Zusammenfassung}

\section{Von der Nichtexistenz und der Normativität der Werte}

Der Artikel hat zum Ziel, zwei Behauptungen zu begründen: 1) dass die Werte nicht zum Bereich des Begriffs der Existenz gehören; 2) dass sie für das Subjekt geltend sind, obwohl sie keine objektive Existenz besitzen. Der erste Teil des Artikels beinhaltet die Kritik der Werteontologie. Im nächsten Teil legt der Verfasser die Argumentation nach folgenden positiven Thesen vor: 1) Wertgegenstände sind Gegenstände der richtigen Gefühle; 2) das Kriterium der Richtigkeit der Gefühle bildet die durch Selbstwissen und Verstand festgestellte Nicht-Widersprüchlichkeit ihrer Inhalte mit dem Glück des Subjekts; 3) der durch freie Entscheidung (Vorentscheidung) bejahte Inhalt des Glücks bildet den Inhalt der ersten axiologischen Prämisse in praktischen Überlegungen; 4) die Quelle des normativen Wertes ist das menschliche Bedürfnis nach Subjektsein, das die Bejahung eigener Freiheit und Rationalität umfasst. Der im 
Artikel vorgeschlagene axiologische Standpunkt befindet sich zwischen zwei kritisierten Extremen: der objektivistischen Werteontologie und dem subjektivistischen Emotivismus.

Schlüsselworte: Werte, Normativität, Glück

Information about Author:

ANDRZEJ NIEMCZUK, habilitated doctor, associate professor, Institute of Philosophy, Faculty of Sociology and History, University of Rzeszów; address for correspondence: al. T. Rejtana 16 C, 35-959 Rzeszów, Poland; e-mail: aniemczuk@ur.edu.pl 